\section{Determining Optimal Bulb Storage and Production Methods for Successful Forcing of Cut Pineapple Lily}

\author{
Alicain S. Carlson ${ }^{1}$ and John M. Dole
}

ADDITIONAL INDEX WORDs. Eucomis, field production, planting density, stem caliper, stem length

SUMmaRY. Pineapple lily (Eucomis hybrids) has long, striking inflorescences that work well as a cut flower, but information is needed on proper production methods and postharvest handling protocols. The objective of this study was to determine the effects of bulb storage temperature and duration, production environment, planting density, and forcing temperatures on cut flower production of 'Coral', 'Cream', 'Lavender', and 'Sparkling Burgundy' pineapple lily. Stem length was greater in the greenhouse than the field and at the low planting density. Plants in the field at the low planting density had the shortest stem length for 'Coral' and 'Cream', but still produced marketable lengths of at least $30 \mathrm{~cm}$. Planting density did not affect 'Lavender' and 'Sparkling Burgundy' stem length or number of marketable stems. The productivity (number of marketable stems per bulb) was affected only by planting density for 'Coral' and planting environment for 'Cream'. Differences in stem quality and productivity differed for each cultivar and planting density over the next two seasons. The productivity of 'Coral' increased significantly from year to year, while the productivity of 'Cream' only significantly increased between the first and second years. The low planting density resulted in slightly more stems per bulb for 'Coral' over the next two seasons. Emergence after bulb storage treatments was highest in treatments where the bulbs were not lifted from the substrate and were subsequently grown at $18{ }^{\circ} \mathrm{C}$. Bulbs grown in the warmest $\left(18^{\circ} \mathrm{C}\right)$ production temperature flowered soonest and had shorter stem lengths. For earliest flowering, bulbs should be stored in substrate in cool temperatures of at least $13{ }^{\circ} \mathrm{C}$ and forced at warm temperatures of at least $18{ }^{\circ} \mathrm{C}$.

$\mathrm{N}$ ew cut flower introductions are necessary to maintain and increase consumer interest. Expanding the availability and knowledge of new cut flowers allows growers to select species and cultivars ideally suited for their climates and consumer base. Many exotic bulb species, such as pineapple lily, are underused by the floral industry. The genus Eucomis contains about 15 species (Bryan and Griffiths, 1995) and many hybridized cultivars now exist that vary in color, scent, vigor, and hardiness (Fig. 1). Pineapple lily grows from a true bulb forming a rosette of lanceolate leaves. From that rosette emerges a spike inflorescence composed of starshaped florets and a terminal tuft of

Department of Horticultural Science, North Carolina State University, Campus Box 7609, Raleigh, NC 27695

We gratefully acknowledge funding by ICFG/Hill Foundation and the Gloeckner Foundation, plant material from a commercial bulb producer, statistical consulting from Joy Smith, and support from the floriculture research technicians, Ingram McCall and Diane Mays, as well as Erin Clark, Qianni Dong, and Brigitte Crawford.

${ }^{1}$ Corresponding author. E-mail: ascarlso@ncsu.edu. bracts making it resemble a pineapple, from which its common name is derived. The inflorescence has the potential to last for more than a month in a vase with proper postharvest handling (Carlson and Dole, 2014) and even longer on the plant. New cultivars and species appear to have potential, but growers are hesitant to produce new cut flower crops without information on production techniques.

Plant material and production area are costly; therefore, it is important that optimum planting densities be identified to maximize financial return (Rees, 1974). Planting density can strongly affect the yield of bulb crops (de Vroomen, 1974), weed and disease control, and mechanization
(Rees, 1974). Increasing planting density to increase productivity per unit area can decrease the productivity per plant, increase stem length, and increase earliness of flowering depending on the species (Rees, 1974). Higher rates of transpiration and reduction in light penetration also occur at higher densities (Rees, 1974). The morphogenic effects of high planting densities may not be seen in the first year because the bulb has sufficient carbohydrate reserves, but future crops may exhibit lower productivity and stem-quality issues (Rees, 1974) making it important to look at the long-term effects of planting densities on perennials. Effects of planting density have not been investigated for pineapple lily.

Growth and flowering of most geophytes is controlled by internal physiological factors, such as dormancy, maturity, bulb storage condition, and forcing temperatures (De Hertogh and Le Nard, 1993). Storage temperature affects the formation of floral organs and the timing of flowering (Hartsema, 1961). In general, temperature is the major environmental factor that influences the flowering process from flower initiation to development in bulb plants (Roh and Hong, 2007). Both temperature and photoperiod are known to affect the formation of floral organs in oriental lily [Lilium longiflorum (Roh and Wilkins, 1978)]. Closely related to pineapple lily, star-of-bethlehem (Ornithogalum thyrsoides) has a relatively shallow dormancy and may continue to grow and flower under favorable environmental conditions and will not enter dormancy (Halevy, 1990). Effective temperature for breaking of dormancy may also vary within species. Little information is known about suitable temperatures for dormancy breaking or flower initiation of pineapple lily.

It is also important for growers to know optimal production temperatures before growing a new crop.

\begin{tabular}{llll}
\hline $\begin{array}{l}\text { Units } \\
\text { To convert U.S. to SI, } \\
\text { multiply by }\end{array}$ & U.S. unit & SI unit & $\begin{array}{l}\text { To convert SI to U.S., } \\
\text { multiply by }\end{array}$ \\
\hline 0.3048 & $\mathrm{ft}$ & $\mathrm{m}$ & 3.2808 \\
2.54 & inch $(\mathrm{es})$ & $\mathrm{cm}$ & 0.3937 \\
25.4 & inch $(\mathrm{es})$ & $\mathrm{mm}$ & 0.0394 \\
1 & ppm & $\mathrm{mg} \cdot \mathrm{L}^{-1}$ & 1 \\
$\left({ }^{\circ} \mathrm{F}-32\right) \div 1.8$ & ${ }^{\circ} \mathrm{F}$ & ${ }^{\circ} \mathrm{C}$ & $\left({ }^{\circ} \mathrm{C} \times 1.8\right)+32$
\end{tabular}



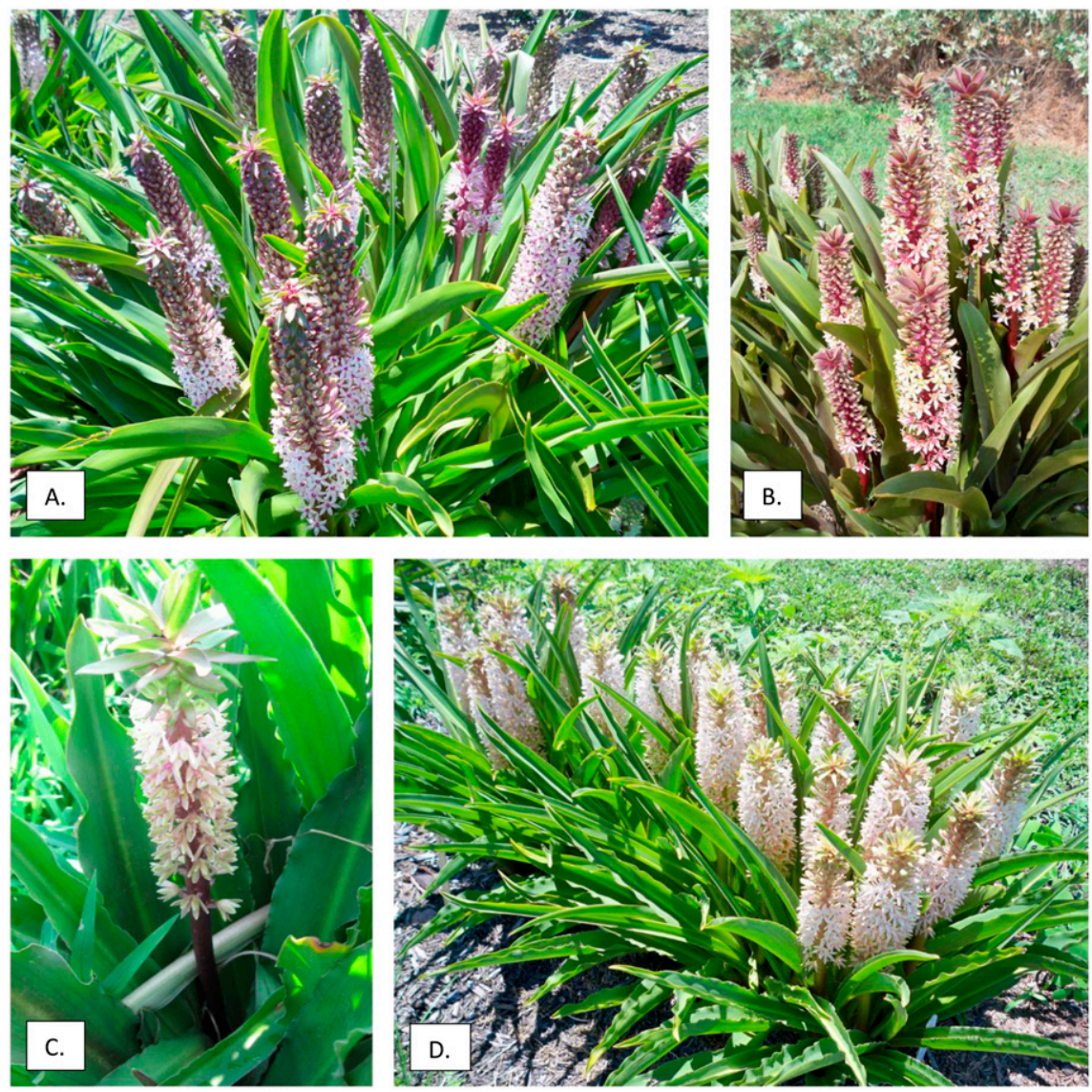

Fig. 1. Four cultivars of pineapple lily during field production: (A) Lavender, (B) Sparkling Burgundy, (C) Cream, and (D) Coral.

Each plant species has a range of temperatures that are tolerable and conducive to plant growth, but extreme temperatures within that range can stress plants resulting in pest/ disease problems, unacceptably long production times, or reduced inflorescence quality (Dole and Wilkins, 2005). Growers may have access to different production environments depending on their individual operations. It is important to understand the differences these production environments will have on the productivity and quality of cut stems.

The objectives of this study were to determine the optimal production environment, planting density, bulb storage duration and temperature, and forcing temperature for 'Coral', 'Cream', 'Lavender', and 'Sparkling Burgundy' pineapple lily.

\section{Materials and methods}

Production environment $\times$ PLANTING DENSITY. Bulbs of 'Coral', 'Cream', and 'Lavender' pineapple lily were received from a commercial supplier on 14 May 2009 and held overnight. 'Sparkling Burgundy' was dug and divided from field beds at North Carolina State University. Bulbs were all planted on 15 May 2009 and grown in either a doublelayered polyethylene-covered greenhouse or loamy clay soil field beds $(3 \times$ $180 \mathrm{ft}$ ) in Raleigh, NC. In the greenhouse, bulbs were planted in lily crates $(22 \times 14.5 \times 9$ inches $)$ using a commercial peat-based root substrate (Fafard 4P Mix; Fafard, Agawam, MA) and grown at $20 \pm 5{ }^{\circ} \mathrm{C}$ night temperatures and ambient air temperatures during the day. In the greenhouse, plants were fertigated with $250 \mathrm{ppm}$ nitrogen $(\mathrm{N})$ from a premixed commercial $20 \mathrm{~N}-4.4 \mathrm{P}-$ 16.6K fertilizer (Peter's, Allentown, PA) when the substrate was dry, but the plant had not wilted. Clear water was used on the weekends. Bulbs in each production environment were planted at a low density of six bulbs per crate $(5 \times 7$-inch spacing between bulbs) or a high density of 12 bulbs per crate $(4 \times 4$-inch spacing $)$. The equivalent spacing was replicated in the field. This resulted in a $2 \times 2$ factorial ( 2 production environments $\times 2$ planting densities) arranged in a completely randomized design with 10 replications (crates/field plots) per treatment for 'Coral', 'Cream', and 'Lavender' and two replications per treatment for 'Sparkling Burgundy'. Stem length and caliper, and number of marketable stems per replication were recorded. Stems were considered marketable if they were greater than $30 \mathrm{~cm}$ in length and had typical inflorescence morphology (multiple leaf-like bracts on top of inflorescence with ovate buds and star-shaped flowers along a smooth stem).

LONG-TERM PLANTING DENSITY. For the bulbs planted in the field in 2009 , data on stem length, caliper, and the number of marketable stems per plot were recorded for 2010 and 2011 for all cultivars.

BULB STORAGE $\times$ FORCING TEMPERATURE. Bulbs of 'Coral', 'Cream', and 'Lavender' grown in the greenhouse from 2009 were no longer watered once flower production ceased and on 9 Sept. 2009, the foliage was removed from all bulbs in one crate per cultivar per density treatment and then stored in one of the following treatments: 1-4) bulbs lifted and placed into paper bags in a dark $13 \pm 2{ }^{\circ} \mathrm{C}$ cooler for either 47 , 54,80 , or $96 \mathrm{~d} ; 5$ ) bulbs remained in substrate and cooled in a dark $13 \pm$ $2{ }^{\circ} \mathrm{C}$ cooler for $\left.47 \mathrm{~d} ; 6\right)$ bulbs left in greenhouse at $18 \pm 3{ }^{\circ} \mathrm{C}$ night $/ 24 \pm$ $4{ }^{\circ} \mathrm{C}$ day temperatures for $47 \mathrm{~d} ; 7$ ) bulbs stored outside at $3 \pm 4{ }^{\circ} \mathrm{C}$ night $/ 16 \pm 3{ }^{\circ} \mathrm{C}$ day temperatures for $47 \mathrm{~d}$.

Bulbs were replanted after storage into lily crates in the same manner as above, except that all bulbs were planted at six bulbs per crate. Bulbs that were stored in substrate remained in the substrate undisturbed. One crate from each storage treatment was placed into double-layered polyethylenecovered greenhouses set to one of three temperature regimes: 1) $18 \pm$ $4{ }^{\circ} \mathrm{C}$ night $/ 22 \pm 5{ }^{\circ} \mathrm{C}$ day, 2) $10 \pm$ $2{ }^{\circ} \mathrm{C}$ night $/ 14 \pm 5^{\circ} \mathrm{C}$ day, or 3$) 2 \pm 3{ }^{\circ} \mathrm{C}$ night/ambient air temperatures during the day. Shoot emergence per crate and shoot height were recorded on 16 Mar. 2010. Stem length and caliper, and number of marketable stems per replication were also recorded. Stems were 
deemed marketable as indicated above.

Statistical analysis. Data were analyzed using analysis of variance (ANOVA) using the general linear model (GLM) procedure and means separated by Tukey's multiple comparison procedure at $\alpha=0.05$ using SAS (version 9.3; SAS Institute, Cary, $\mathrm{NC}$ ). The crate or plot was used as the experimental unit. For long-term planting density data were analyzed using repeated measures ANOVA using plot as the experimental unit and means were separates using least significant differences at $\alpha=0.05$.

\section{Results}

\section{Production environment $\times$ density}

All cultivars. In year 1 'Sparkling Burgundy' had the longest stem length of $61.7 \mathrm{~cm}$ and 'Lavender' had the shortest of $40.9 \mathrm{~cm}$, while 'Coral' and 'Cream' were intermediate at 53.2 and $53.4 \mathrm{~cm}$, respectively $(P<$ $0.001)$. 'Cream' and 'Sparkling Burgundy' had the thickest stem calipers of 15.4 and $15.3 \mathrm{~mm}$, respectively; 'Lavender' had the thinnest of 10.2 and 'Coral was intermediate at $12.7 \mathrm{~mm}$ $(P<0.001)$. 'Coral' and 'Cream' produced the most stems per bulb of 1.2 and 1.0, respectively, while, 'Lavender' and 'Sparkling Burgundy' produced the least of 0.6 and 0.6 , respectively $(P<0.001)$. Since there were significant differences among cultivars, they were further analyzed separately.

'Coral'. Planting environment and density interacted such that bulbs in the field at the low density resulted in the shortest stem length of $46.5 \mathrm{~cm}$, while bulbs in the greenhouse at the low density had the longest stem length of $58.8 \mathrm{~cm}$, which did not differ from bulbs in the greenhouse at the high density of $56.9 \mathrm{~cm}(P<$ $0.001)$. Stems in the field planted at the high density were intermediate in stem length at $49.8 \mathrm{~cm}$. Stem caliper in the field at both planting densities did not differ from one another with $12.1 \mathrm{~mm}$ at the low density and $11.8 \mathrm{~mm}$ at the high density, but stem calipers at each density were significantly lower than those in the greenhouse, 14.0 and $12.9 \mathrm{~mm}$, respectively. The number of marketable stems per plant was 1.3 when planted at the low density and 1.1 at the high density. Neither production environment nor the interaction of environment and planting density had an effect on the number of marketable stems.

'CREAM'. Planting environment and density interacted such that stems in the field at the low density resulted in the shortest stem length of $36.7 \mathrm{~cm}$, while stems in the greenhouse at the low density had the longest stem length of $53.8 \mathrm{~cm}$, which did not differ from bulbs in the greenhouse at the high density of $53.2 \mathrm{~cm}(P=0.021)$. Stems in the field planted at the high density were intermediate in stem length at $39.2 \mathrm{~cm}$. Stem caliper in the field at both planting densities did not differ from one another with $13.8 \mathrm{~mm}$ at the low density and $13.1 \mathrm{~mm}$ at the high density, but stem calipers at each density were significantly lower than those in the greenhouse $(P=0.039)$, 16.5 and $14.8 \mathrm{~mm}$, respectively. Bulbs planted in the greenhouse had more marketable stems per plant (1.1) than those planted in the field $(0.9)$. Neither planting density nor the interaction of planting density and environment had an effect on the number of marketable stems.

'LAVENDER'. Stem length was greater in the greenhouse at $44.0 \mathrm{~cm}$ than in the field at $38.1 \mathrm{~cm}(P=$ $0.021)$ and unaffected by planting density. Stem caliper was reduced from $11.1 \mathrm{~mm}$ in the low density to $9.8 \mathrm{~mm}$ in the high density $(P<$ $0.001)$ and unaffected by production environment. Neither planting density nor production environment had an effect on marketable stem number. There were no significant interactions.

'Sparkling Burgundy'. Stem length and caliper were greater in the greenhouse $(68.6 \mathrm{~cm}$ and $16.4 \mathrm{~mm}$, respectively) than in the field $(54.5 \mathrm{~cm}$ and $14.5 \mathrm{~mm}$, respectively $)(P<0.001$ and $P=0.025$, respectively). Neither planting density nor production environment affected marketable stem number. Planting density did not affect any parameters measured and there were no significant interactions.

\section{Long-term planting density}

All Cultivars. Differences existed among cultivars for stem length $(P<0.001)$ and number of marketable stems per bulb $(P<$ $0.001)$ so the cultivars were analyzed separately for further interpretation of the effects of long-term planting densities (Table 1). Stem caliper did not differ among cultivars.

'SPARKLING Burgundy'. Over the 3 years the number of marketable stems per bulb increased $(P=0.033$; Table 2 ). Stem length was affected by year such that it significantly increased from 2009 to 2010 and then decreased from 2010 to $2011(P=$ 0.007; Table 3). No significant interactions occurred between density and year. Stem caliper was not influenced by density or year.

'Coral'. Planting density affected the number of marketable stems per bulb with the low-density plantings yielding 2.5 stems per bulb and the high-density plantings yielding 2.1 stems per bulb $(P<0.001)$. Stem caliper was greater in the lowdensity plantings $(13.5 \mathrm{~mm})$ compared with the high-density plantings $(12.8 \mathrm{~mm})(P=0.033)$. Over the 3 years, the number of marketable stems per bulb significantly increased (Table 2). Stem length (Table 3 ) and diameter (Table 4) were affected by year such that both significantly

Table 1. Effect of cultivar on stem length and marketable stems averaged over 3 years of production on 'Sparkling Burgundy', 'Coral', 'Cream', and 'Lavender' pineapple lily. A stem was considered marketable if it was at least $30 \mathrm{~cm}$ long and had no abnormal development.

\begin{tabular}{lcc}
\hline Cultivar & Stem length $(\mathrm{cm})^{\mathrm{z}}$ & Stems $($ no./bulb) \\
\hline Sparkling Burgundy & $75.4 \mathrm{a}^{\mathrm{y}}$ & $1.0 \mathrm{~b}$ \\
Coral & $60.2 \mathrm{c}$ & $2.3 \mathrm{a}$ \\
Cream & $50.6 \mathrm{~d}$ & $1.5 \mathrm{~b}$ \\
Lavender & $65.5 \mathrm{~b}$ & $1.5 \mathrm{~b}$ \\
Significance $^{\mathrm{x}}$ & $<0.001$ & $<0.001$ \\
\hline
\end{tabular}

${ }^{2} 1 \mathrm{~cm}=0.3937$ inch.

${ }^{y}$ Means followed by the same letter are not significantly different according to least significant differences procedure at $\alpha=0.05$.

${ }^{x}$ Probability values were obtained using repeated measures analysis of variance of SAS (version 9.3; SAS Institute, Cary, NC). 
increased from 2009 to 2010 and then decreased from 2010 to 2011 $(P<0.001)$. In addition, there was a significant interaction between year and density affecting stem length and the number of marketable stems $(P=$ 0.006; Table 5).

'Cream'. Year affected the number of marketable stems per bulb causing it to increase from year to year $(P<0.001$; Table 2$)$. Year also affected stem length in that it increased from 2009 to 2010 and then decreased from 2010 to 2011 $(P<0.001 ;$ Table 3$)$. In addition, stem caliper decreased from 2010 $(13.1 \mathrm{~mm})$ to $2011(10.5 \mathrm{~mm})(P<$ 0.001 ; Table 4). Stem caliper was greater in the low-density planting $(12.8 \mathrm{~mm})$ compared with the highdensity planting $(11.9 \mathrm{~mm})(P=$ $0.001)$. There were no significant interactions between year and density. Density did not influence the number of marketable stems per bulb.

'LAVENDER'. The number of marketable stems per bulb increased from year to year (Table 2). From 2009 to 2010 stem length (Table 3) and caliper (Table 4) increased significantly and from 2010 to 2011 there were no significant changes. The greater planting density decreased stem caliper from 14.5 to $13.0 \mathrm{~mm}$ $(P=0.011)$. There were no significant interactions between density and year. Density did not affect the number of marketable stems per bulb.

\section{Bulb storage temperature and duration $\times$ forcing temperature}

'Coral'. The tallest shoots of $25.9 \mathrm{~cm}$ were from bulbs stored for $47 \mathrm{~d}$ outside in the substrate and forced at $18{ }^{\circ} \mathrm{C}$ (Table 6 ). This treatment also had the greatest number of shoots emerged per bulb of 3.2. Bulbs stored for $47 \mathrm{~d}$ in substrate in the greenhouse and forced at $18{ }^{\circ} \mathrm{C}$ were the second-most productive and had a shoot height of $19.8 \mathrm{~cm}$. However, these shoot heights did not differ from bulbs stored for $96 \mathrm{~d}$ in the cooler removed from the substrate and forced at $18{ }^{\circ} \mathrm{C}(18.5 \mathrm{~cm})$. The least number of shoots per bulb (0.2) was in the treatment stored for $54 \mathrm{~d}$ in the cooler removed from the substrate and forced at $2{ }^{\circ} \mathrm{C}$.

Bulbs forced at $18{ }^{\circ} \mathrm{C}$ had a shorter stem length of $50.8 \mathrm{~cm}$ compared with bulbs forced at 10 and $2{ }^{\circ} \mathrm{C}$, which had lengths of 55.6 and $53.9 \mathrm{~cm}$, respectively. The $2{ }^{\circ} \mathrm{C}$ forcing temperature resulted in the thickest stem caliper of $13.5 \mathrm{~mm}$. The
10 and $18{ }^{\circ} \mathrm{C}$ temperatures both resulted in a $12.1-\mathrm{mm}$ caliper. Days to flowering were also reduced in the

Table 2. Effects of year on marketable stems for 'Sparkling Burgundy', 'Coral', 'Cream', and 'Lavender' pineapple lily. A stem was considered marketable if it was at least $30 \mathrm{~cm}$ (11.8 inches) long and had no abnormal development.

\begin{tabular}{|c|c|c|c|c|}
\hline \multirow[b]{2}{*}{ Yr } & Sparkling Burgundy & Coral & Cream & Lavender \\
\hline & \multicolumn{4}{|c|}{ Marketable stems (no./bulb) } \\
\hline 2009 & $0.6 b^{z}$ & $1.2 \mathrm{c}$ & $1.0 \mathrm{c}$ & $1.0 \mathrm{c}$ \\
\hline 2010 & $1.1 \mathrm{ab}$ & $2.4 \mathrm{~b}$ & $1.9 \mathrm{a}$ & $1.5 \mathrm{~b}$ \\
\hline 2011 & $1.4 \mathrm{a}$ & $3.4 \mathrm{a}$ & $1.6 \mathrm{~b}$ & $1.8 \mathrm{a}$ \\
\hline Significance $^{\mathrm{y}}$ & 0.033 & $<0.001$ & $<0.001$ & $<0.001$ \\
\hline
\end{tabular}

${ }^{\mathrm{z}}$ Means followed by the same letter are not significantly different according to least significant differences procedure at $\alpha=0.05$.

y Probability values were obtained using repeated measures analysis of variance of SAS (version 9.3; SAS Institute, Cary, NC).

Table 3. Effects of year on stem length of 'Sparkling Burgundy', 'Coral', 'Cream', and 'Lavender' pineapple lily.

\begin{tabular}{lcccc}
\hline & Sparkling Burgundy & Coral & Cream & Lavender \\
\cline { 2 - 5 } Yr & $54.8 \mathrm{~b}^{\mathrm{y}}$ & Stem length $(\mathrm{cm})^{\mathrm{z}}$ & \\
\hline 2009 & $84.1 \mathrm{a}$ & $48.3 \mathrm{c}$ & $37.9 \mathrm{c}$ & $43.0 \mathrm{~b}$ \\
2010 & $78.1 \mathrm{a}$ & $64.6 \mathrm{a}$ & $56.9 \mathrm{a}$ & $72.5 \mathrm{a}$ \\
2011 & 0.007 & $61.2 \mathrm{~b}$ & $49.4 \mathrm{~b}$ & $76.1 \mathrm{a}$ \\
Significance $^{\mathrm{x}}$ & \multicolumn{4}{c}{} \\
\hline
\end{tabular}

${ }^{\mathrm{z}} 1 \mathrm{~cm}=0.3937$ inch.

${ }^{y}$ Means followed by the same letter are not significantly different according to least significant differences procedure at $\alpha=0.05$.

${ }^{x}$ Probability values were obtained using repeated measures analysis of variance of SAS (version 9.3; SAS Institute, Cary, NC).

Table 4. Effect of year on stem caliper of 'Coral', 'Cream', and 'Lavender' pineapple lily planted at two different planting densities ( 6 or 12 bulbs/plot).

\begin{tabular}{lccc}
\hline & 'Coral' & 'Cream' & 'Lavender' \\
\cline { 2 - 4 } Yr & & Stem caliper $(\mathbf{m m})^{\mathrm{z}}$ & \\
\hline 2009 & $12.1 \mathrm{c}^{\mathrm{y}}$ & $13.4 \mathrm{a}$ & $10.0 \mathrm{~b}$ \\
2010 & $14.2 \mathrm{a}$ & $13.1 \mathrm{a}$ & $14.8 \mathrm{a}$ \\
2011 & $13.2 \mathrm{~b}$ & $10.5 \mathrm{~b}$ & $14.6 \mathrm{a}$ \\
Significance $^{\mathrm{x}}$ & $<0.001$ & $<0.001$ & $<0.001$ \\
\hline
\end{tabular}

${ }^{\mathrm{z}} 1 \mathrm{~mm}=0.0394$ inch.

${ }^{y}$ Means followed by the same letter are not significantly different according to least significant differences procedure at $\alpha=0.05$.

xProbability values were obtained using repeated measures analysis of variance of SAS (version 9.3; SAS Institute, Cary, NC).

Table 5. Effects of the interaction of planting density and year on stem length and number of marketable stems of 'Coral' pineapple lily. The low-density plantings were 6 bulbs/plot and high-density plantings were 12 bulbs/plot.

\begin{tabular}{lccc}
\hline Planting density & Yr & Stem length $(\mathrm{cm})^{\mathrm{z}}$ & Marketable stems (no./bulb) \\
\hline Low & 2009 & $46.5 \mathrm{e}^{\mathrm{y}}$ & $1.3 \mathrm{f}$ \\
& 2010 & $64.1 \mathrm{ab}$ & $2.4 \mathrm{~d}$ \\
& 2011 & $62.3 \mathrm{bc}$ & $3.9 \mathrm{c}$ \\
High & 2009 & $49.8 \mathrm{~d}$ & $1.1 \mathrm{e}$ \\
& 2010 & $65.3 \mathrm{a}$ & $2.4 \mathrm{~b}$ \\
& 2011 & $60.1 \mathrm{c}$ & $2.9 \mathrm{a}$ \\
Significance $^{\mathrm{x}}$ & & 0.012 & 0.006 \\
\hline
\end{tabular}

${ }^{\mathrm{z}} \mathrm{l} \mathrm{cm}=0.3937$ inch.

${ }^{y}$ Means followed by the same letter are not significantly different according to least significant differences procedure at $\alpha=0.05$.

xProbability values were obtained using repeated measures analysis of variance of SAS (version 9.3; SAS Institute, Cary, NC). 
Table 6. Effect of forcing temperature and bulb storage treatment on the shoot height and shoot emergence of 'Coral', 'Cream', and 'Lavender' pineapple lily. Once flower production ceased, bulbs were stored in one of the following treatments: bulbs lifted and placed into paper bags in the dark at $13 \pm 2{ }^{\circ} \mathrm{C}$ (cooler) for either $47,54,80$, or $96 \mathrm{~d}$ or bulbs remained in substrate and placed in the dark at $13 \pm 2{ }^{\circ} \mathrm{C}$ for $47 \mathrm{~d}$, left in greenhouse for $47 \mathrm{~d}$, or stored outside for $47 \mathrm{~d}$. After storage, bulbs were planted and forced at either 2,10 , or $18^{\circ} \mathrm{C}$ in a greenhouse. Shoot emergence and height were recorded on 16 Mar. 2010.

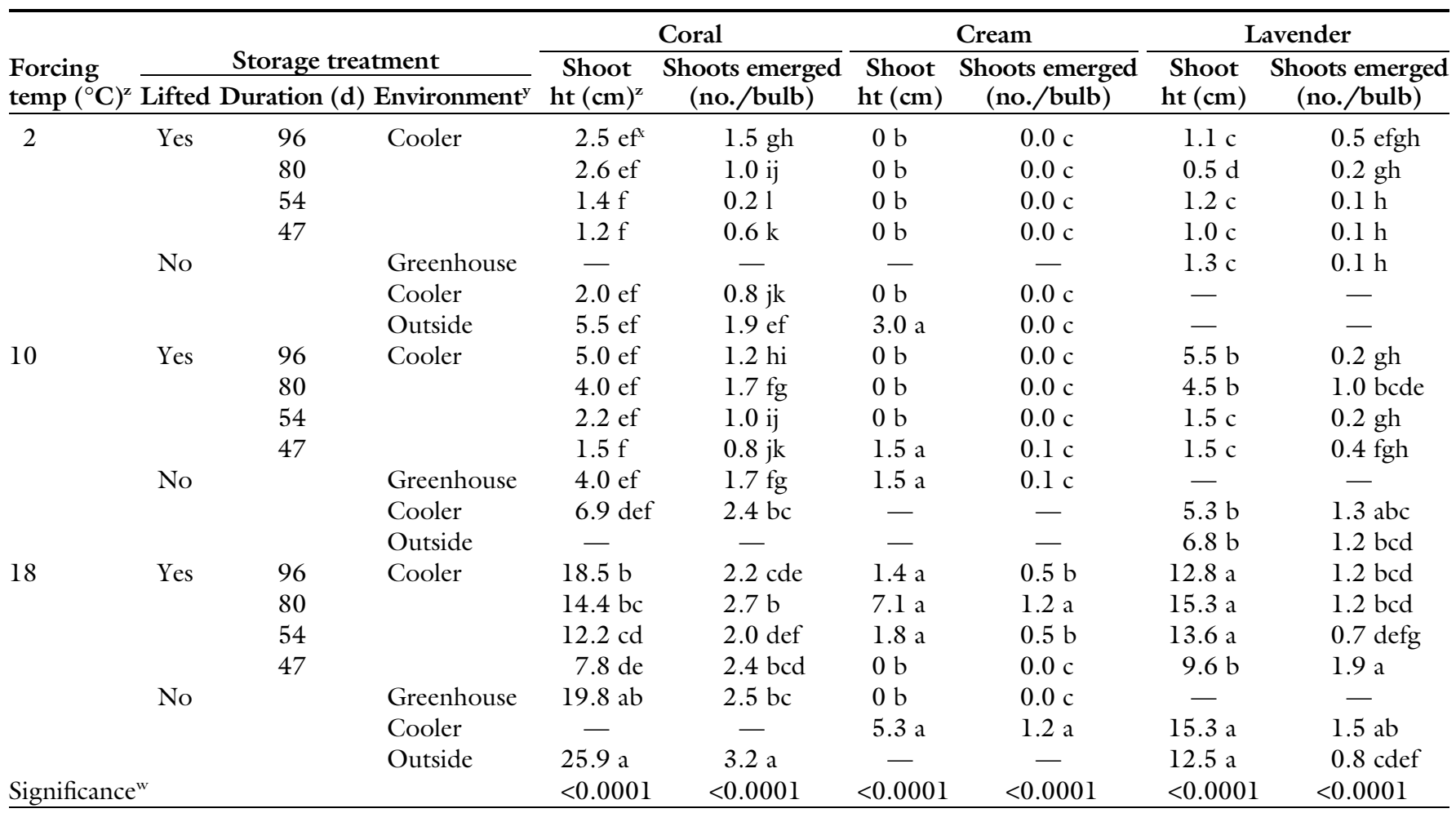

${ }^{\mathrm{z}}\left(1.8 \times{ }^{\circ} \mathrm{C}\right)+32={ }^{\circ} \mathrm{F}, \mathrm{lcm}=0.3937$ inch

${ }^{y}$ Greenhouse $=3 \pm 4 / 16 \pm 3{ }^{\circ} \mathrm{C}$ (night/day) temperatures, Raleigh, NC, from 1 Nov. 2009 to 14 Dec. 2009 ; Outside $=18 \pm 3 / 24 \pm 4{ }^{\circ} \mathrm{C}$ (night $/$ day) temperatures, unheated double-layered polyethylene-covered greenhouse.

${ }^{x}$ Means followed by the same letter are not significantly different according to Tukey's multiple comparison procedure at $\alpha=0.05$

"Probability values were obtained using GLM procedures of SAS (version 9.3; SAS Institute, Cary, NC).

$18{ }^{\circ} \mathrm{C}$ forcing temperature to 176 from $193 \mathrm{~d}$ for the $10^{\circ} \mathrm{C}$ temperature and $199 \mathrm{~d}$ for the $2{ }^{\circ} \mathrm{C}$ temperature. The number of marketable stems produced from each bulb in the $18{ }^{\circ} \mathrm{C}$ temperature was lower (1.4) than in the 2 and $10{ }^{\circ} \mathrm{C}$ temperatures $(1.8$ and 1.9 , respectively). Temperature did not affect the number of marketable stems.

Bulbs stored for $47 \mathrm{~d}$ in the greenhouse in the substrate and grown at $18{ }^{\circ} \mathrm{C}$ produced the shortest stem length of $43.5 \mathrm{~cm}$, whereas those stored in the same manner but grown at $10{ }^{\circ} \mathrm{C}$ had the longest stem length of $62.5 \mathrm{~cm}$ (Table 7). The thinnest stem caliper of $10.7 \mathrm{~mm}$ was also produced by the bulbs stored for $47 \mathrm{~d}$ in the greenhouse in the substrate and grown at $18{ }^{\circ} \mathrm{C}$. The thickest stem calipers of 14.5 and $14.7 \mathrm{~mm}$ were from bulbs stored for $47 \mathrm{~d}$ in the cooler in the substrate and grown at $2{ }^{\circ} \mathrm{C}$ and stored for $80 \mathrm{~d}$ in the cooler removed from the substrate and grown at $2{ }^{\circ} \mathrm{C}$, respectively. The number of marketable stems was lowest for bulbs stored for $47 \mathrm{~d}$ in the greenhouse in the substrate and grown at $18{ }^{\circ} \mathrm{C}(76 \%)$. Bulbs stored for $96 \mathrm{~d}$ in the cooler removed from the substrate and grown at $10^{\circ} \mathrm{C}$ as well as those stored for $47 \mathrm{~d}$ outside in the substrate had similar marketability of $78 \%$ and $79 \%$, respectively. The highest number of stems per bulb of 2.3 was produced by bulbs stored for $47 \mathrm{~d}$ outside in the substrate and grown at $18^{\circ} \mathrm{C}$. Days to flowering was least for bulbs stored for $96 \mathrm{~d}$ in the cooler removed from the substrate and grown at $18{ }^{\circ} \mathrm{C}$ $(162 \mathrm{~d})$. Days to flowering was greatest for bulbs stored for 47 or $54 \mathrm{~d}$ in the cooler removed from the substrate and grown at $2{ }^{\circ} \mathrm{C}(207$ and $205 \mathrm{~d}$, respectively).

'Cream'. The greatest shoot length $(5.3 \mathrm{~cm})$ and number of shoots per bulb (1.2) were from bulbs stored for $47 \mathrm{~d}$ in the cooler in the substrate and forced at $18^{\circ} \mathrm{C}$ (Table $6)$. 'Cream' had the least emergence of all the cultivars and was very slow growing in general.

The $2{ }^{\circ} \mathrm{C}$ forcing temperature significantly reduced stem length to $47.7 \mathrm{~cm}$ from $52.9 \mathrm{~cm}$ for $10^{\circ} \mathrm{C}$ and $52.6 \mathrm{~cm}$ for $18{ }^{\circ} \mathrm{C}$. The number of marketable stems produced per bulb was greatest in the $10^{\circ} \mathrm{C}$ temperature (0.9), least in the $18{ }^{\circ} \mathrm{C}$ temperature (0.5), and moderate in the $2{ }^{\circ} \mathrm{C}$ temperature (0.7). Days to flower was shortest at the $18{ }^{\circ} \mathrm{C}$ forcing temperature $(201 \mathrm{~d})$ and longest in the $2^{\circ} \mathrm{C}$ and $10{ }^{\circ} \mathrm{C}$ temperatures $(213$ and $209 \mathrm{~d}$, respectively). Temperature did not affect stem caliper.

The smallest number of stems per bulb of 0.1 was produced by the bulbs stored for $96 \mathrm{~d}$ in the cooler removed from the substrate and grown in $2{ }^{\circ} \mathrm{C}$ production temperature (Table 8 ). The greatest number of stems per bulb of 1.3 was produced by bulbs stored for $47 \mathrm{~d}$ outside 
Table 7. Effect of production temperature and bulb storage treatment of 'Coral' pineapple lily on stem length, caliper, number of stems per bulb, days to flower, and number of marketable stems. Bulbs were stored in one of the following treatments: bulbs lifted and stored at $13 \pm 5^{\circ} \mathrm{C}$ (cooler) for either $47,54,80$, or $96 \mathrm{~d}$ or bulbs remained in substrate stored at $13^{\circ} \mathrm{C}$, left in greenhouse, or stored outside for $47 \mathrm{~d}$. After storage, bulbs were planted and forced at either 2,10 , or $18{ }^{\circ} \mathrm{C}$ in a greenhouse.

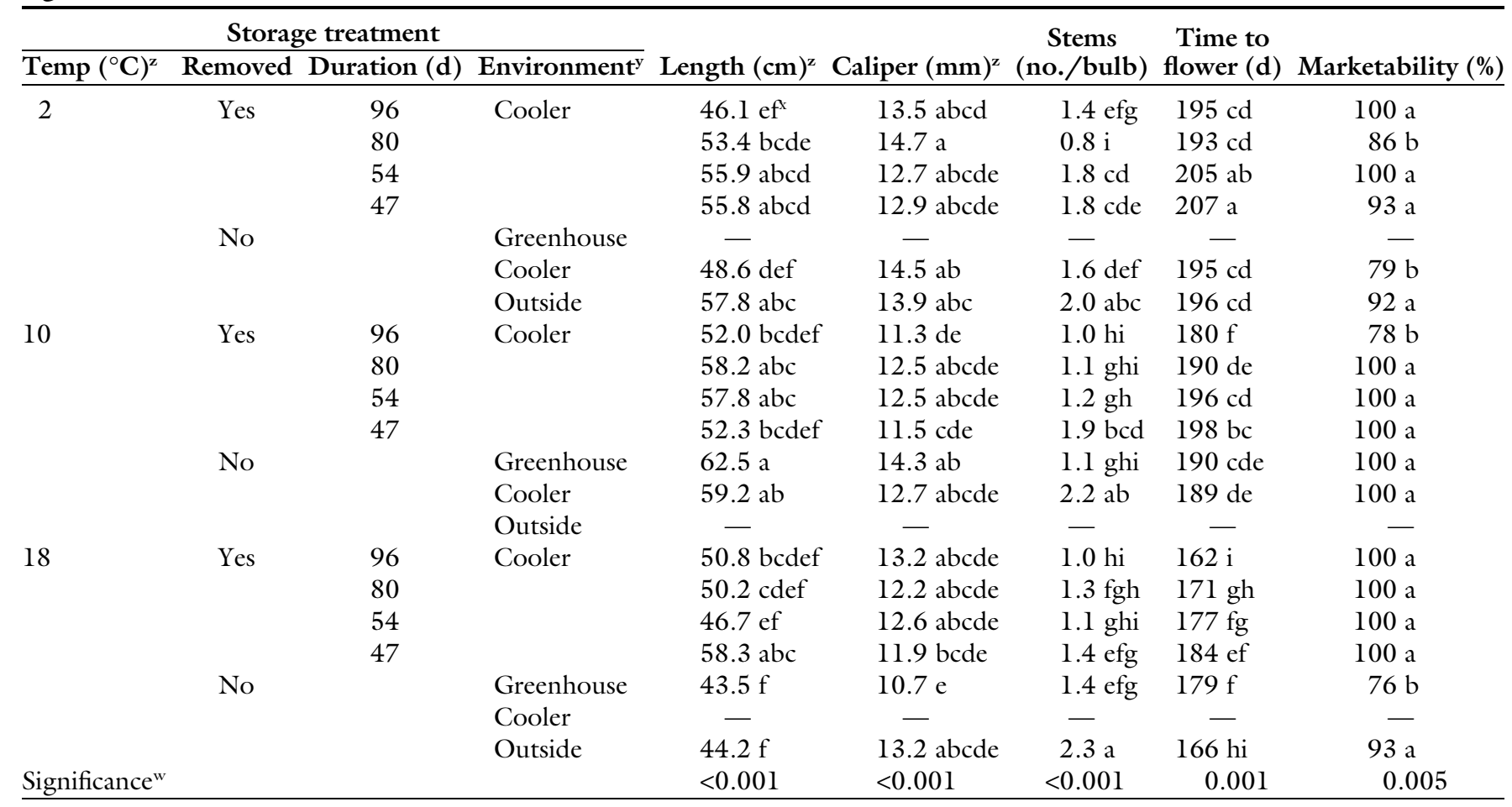

${ }^{\mathrm{z}}\left(1.8 \times{ }^{\circ} \mathrm{C}\right)+32={ }^{\circ} \mathrm{F}, 1 \mathrm{~cm}=0.3937$ inch, $1 \mathrm{~mm}=0.0394$ inch.

${ }^{y}$ Greenhouse $=3 \pm 4 / 16 \pm 3{ }^{\circ} \mathrm{C}$ (night/day) temperatures, Raleigh, NC, from 1 Nov. 2009 to 14 Dec. $2009 ;$ Outside $=18 \pm 3 / 24 \pm 4{ }^{\circ} \mathrm{C}$ (night $/$ day) temperatures, unheated double-layered polyethylene-covered greenhouse.

${ }^{x}$ Means followed by the same letter are not significantly different according to Tukey's multiple comparison procedure at $\alpha=0.05$

"Probability values were obtained using GLM procedures of SAS (version 9.3; SAS Institute, Cary, NC).

in the substrate and grown at $2{ }^{\circ} \mathrm{C}$. The interaction between bulb storage treatment and production temperature did not affect stem length, caliper, marketability, or days to flower.

'LAVENDER'. Bulbs grown at $18{ }^{\circ} \mathrm{C}$ and either stored for $47 \mathrm{~d}$ in the cooler in the substrate or grown at $18{ }^{\circ} \mathrm{C}$ had the greatest emergence of $15.3 \mathrm{~cm}$ and 1.5 shoots per bulb (Table 6). The greatest number of shoots per bulb was 1.9 from the bulbs stored for $47 \mathrm{~d}$ in the cooler removed from the substrate and grown at $18{ }^{\circ} \mathrm{C}$.

Bulbs forced at $10{ }^{\circ} \mathrm{C}$ produced the longest stem length of $76.3 \mathrm{~cm}$, while bulbs at the 2 and $18{ }^{\circ} \mathrm{C}$ temperatures produced stem lengths of 64.6 and $59.6 \mathrm{~cm}$. Stem marketability declined as temperatures went from $2(100 \%)$ to $10(94 \%)$ to $18{ }^{\circ} \mathrm{C}$ $(88 \%)$. Days to flower was least in the $18{ }^{\circ} \mathrm{C}$ temperature at $190 \mathrm{~d}, 10^{\circ} \mathrm{C}$ at $199 \mathrm{~d}$, and $2{ }^{\circ} \mathrm{C}$ at $208 \mathrm{~d}$. The number of stems per bulb was also greatest in the $2{ }^{\circ} \mathrm{C}$ forcing temperature at 0.8 . The 10 and $18{ }^{\circ} \mathrm{C}$ declined to 0.7 and 0.6 stems per bulb. Forcing temperature did not affect stem caliper.

Bulbs stored for $54 \mathrm{~d}$ in the cooler removed from the substrate and grown in $10^{\circ} \mathrm{C}$ production temperature and had the shortest flowering time of $171 \mathrm{~d}$ (Table 9). Bulbs stored for $54 \mathrm{~d}$ in the cooler removed from the substrate and grown at $2{ }^{\circ} \mathrm{C}$ had the longest flowering time of $212 \mathrm{~d}$. Bulbs stored for $47 \mathrm{~d}$ in the cooler in the substrate and grown at $10{ }^{\circ} \mathrm{C}$ had the greatest number of marketable stems per bulb of 1.8. Bulbs stored for 96 and $80 \mathrm{~d}$ in the cooler removed from the substrate produced no stems. The interaction of bulb storage treatment and production temperature did not affect stem length and caliper.

\section{Discussion}

All of the pineapple lily cultivars in this study could be grown in either the open field or greenhouse and produce marketable stems. This allows growers the flexibility to choose which environment best suits their needs. Growers with limited field space could produce a crop in the greenhouse in $\approx 2$ months when planted in May without a large space commitment, while those with field space available for one or several years could benefit from the perennial plantings. Stems were consistently longer in the greenhouse than in the field, which may be due to the reduced light intensity or air movement from the plastic covering on the greenhouse (Wien, 2009). Ortiz et al. (2012) also found the stem lengths of two snapdragon (Antirrbinum majus) cultivars, lisianthus (Eustoma russellianum), sunflower (Helianthus annuus), stock (Matthiola incana), and zinnia (Zinnia elegans) to be longer in a high tunnel compared with those that were field grown. Stem caliper was also greater in the greenhouse than in the field. 
Table 8. The effect of bulb storage treatment and production temperature of 'Cream' pineapple lily on number of stems per bulb. Once flower production ceased, bulbs were stored in one of the following treatments: bulbs lifted and placed into open plastic bags in the dark at $13 \pm 5^{\circ} \mathrm{C}$ (cooler) for either 47,54 , 80 , or $96 \mathrm{~d}$ or bulbs remained in substrate and placed in the dark at $13{ }^{\circ} \mathrm{C}$ for $47 \mathrm{~d}$, left in greenhouse for $47 \mathrm{~d}$, or stored outside for $47 \mathrm{~d}$. After storage, bulbs were planted and forced at either 2,10 , or $18{ }^{\circ} \mathrm{C}$ in a greenhouse.

\begin{tabular}{|c|c|c|c|c|}
\hline \multicolumn{4}{|c|}{ Storage treatment } & \multirow[b]{2}{*}{ Stems (no./bulb) } \\
\hline $\operatorname{Temp}\left({ }^{\circ} \mathrm{C}\right)^{\mathrm{z}}$ & Removed & Duration (d) & Environment $^{\mathrm{y}}$ & \\
\hline \multirow[t]{7}{*}{2} & Yes & 96 & Cooler & $0.1 \mathrm{f}^{\mathrm{x}}$ \\
\hline & & 80 & & $0.3 \mathrm{ef}$ \\
\hline & & 54 & & $0.7 \mathrm{~cd}$ \\
\hline & & 47 & & $0.7 \mathrm{bcd}$ \\
\hline & No & & Greenhouse & - \\
\hline & & & Cooler & $0.8 \mathrm{bc}$ \\
\hline & & & Outside & $1.3 \mathrm{a}$ \\
\hline \multirow[t]{7}{*}{10} & Yes & 96 & Cooler & $0.6 \mathrm{cde}$ \\
\hline & & 80 & & $0.6 \mathrm{cde}$ \\
\hline & & 54 & & $0.3 \mathrm{def}$ \\
\hline & & 47 & & $1.1 \mathrm{ab}$ \\
\hline & No & & Greenhouse & $0.6 \mathrm{cde}$ \\
\hline & & & Cooler & - \\
\hline & & & Outside & $0.8 \mathrm{bc}$ \\
\hline \multirow[t]{7}{*}{18} & Yes & 96 & Cooler & $0.6 \mathrm{cde}$ \\
\hline & & 80 & & $0.4 \mathrm{cdef}$ \\
\hline & & 54 & & 0.4 cdef \\
\hline & & 47 & & $0.6 \mathrm{cde}$ \\
\hline & No & & Greenhouse & $0.5 \mathrm{cdef}$ \\
\hline & & & Cooler & $0.8 \mathrm{bc}$ \\
\hline & & & Outside & - \\
\hline Significance $^{\mathrm{w}}$ & & & & $<0.001$ \\
\hline
\end{tabular}

${ }^{\mathrm{z}}\left(1.8 \times{ }^{\circ} \mathrm{C}\right)+32={ }^{\circ} \mathrm{F}$.

${ }^{y}$ Greenhouse $=3 \pm 4 / 16 \pm 3{ }^{\circ} \mathrm{C}$ (night/day) temperatures, Raleigh, NC, from 1 Nov. 2009 to 14 Dec. 2009; Outside $=18 \pm 3 / 24 \pm 4{ }^{\circ} \mathrm{C}$ (night/day) temperatures, unheated double-layered polyethylene-covered greenhouse.

${ }^{x}$ Means followed by the same letter are not significantly different according to Tukey's multiple comparison procedure at $\alpha=0.05$.

wProbability values were obtained using GLM procedures of SAS (version 9.3; SAS Institute, Cary, NC).

An increase in stem length and caliper usually equates to better stem strength and higher quality cuts (Ortiz et al., 2012). This suggests that it may be beneficial to grow pineapple lily in a high tunnel or under a shade structure. The extra protection early in the season may also help to reduce time to flowering. The high planting density would be ideal for greenhouses with limited space since more stems per unit area could be obtained. This study shows that planting up to 12 bulbs per lily crate did not severely affect stem quality. Field production may be better served by low planting densities to facilitate subsequent years' bulb offsets. In the field, the higher density increased stem length. This is similar to calla lily (Zantedeschia aethiopica) where close planting densities increased stem length and did not affect the number of flowers produced (Luria et al., 2005).
Three years of production information gave us valuable data for effects of the two different planting densities long term. Stem quality (length and caliper) increased for all cultivars from 2009 to 2010 , but did not change significantly from 2010 to 2011. 'Coral' was an exceptional cultivar that increased productivity and stem quality every year regardless of the planting density, but the low planting density had one more stem per bulb than the high planting density. 'Sparkling Burgundy' and 'Lavender' increased production without reducing quality at both densities over the three seasons, while 'Cream' production slightly decreased for both planting densities. For the long term, bulbs should be planted at a wider spacing and lower planting density to give the bulblets from the original mother bulb room to grow and access to resources.
As seen in this study, the flowering of pineapple lily depended greatly on temperature. Bulbs in the $18{ }^{\circ} \mathrm{C}$ production temperature emerged faster and flowered sooner than those in the cooler temperatures. Flower initiation in pineapple lily could be caused by a critical temperature and duration, which when reached, halts stem elongation and causes the inflorescence to mature. This would account for the shortened stem length in the warmest production temperature. In addition, the shortened stem lengths were not significant enough to affect marketability, which was defined as having a stem length of at least $30 \mathrm{~cm}$ and no malformations. While it is beneficial to have cut flowers available early in the season for Easter and Mother's Day sales, the extra costs associated with heating a greenhouse to speed flowering may or may not be worth the benefits.

Fast-growing cultivars like Coral, which had the greatest emergence and was the first to flower in the field and greenhouse, would be ideal to hasten the time to flowering. Not considering the cultivar and production temperature, bulbs stored in the substrate either outside or in the cooler had greater shoot numbers and shoot lengths. The faster shoot growth of bulbs stored in substrate compared with bulbs removed from the substrate was most likely due to the root system remaining intact. A clear trend in 'Coral' emergence occurred in all production temperatures resulting in bulbs removed from the substrate, as storage time increased shoot height also increased. Roh et al. (2007) found that the speed of leaf emergence of star-of-bethlehem can be used to measure the level of dormancy, as well as in oriental lily (De Hertogh et al., 1971). Our data suggest that the bulbs harvested first and stored the longest (96 d) were the least dormant and that the dormancy decreased as storage length increased.

Pineapple lily benefits from a cold period, which may be cumulative and facultative. These characteristics would be an added benefit to field production since bulbs do not need to be dug after the production season, as long as they were being grown in the appropriate zone, and would undergo natural vernalization while overwintering. Most pineapple lilies 
Table 9. The effect of bulb storage treatment and production temperature on the number of stems per bulb of 'Lavender' pineapple lily. Once flower production ceased, bulbs were stored in one of the following treatments: bulbs lifted and placed into open plastic bags in the dark at $13 \pm 5^{\circ} \mathrm{C}$ (cooler) for either $47,54,80$, or $96 \mathrm{~d}$ or bulbs remained in substrate and placed in the dark at $13{ }^{\circ} \mathrm{C}$ for $47 \mathrm{~d}$, left in greenhouse for $47 \mathrm{~d}$, or stored outside for $47 \mathrm{~d}$. After storage, bulbs were planted and forced at either 2,10 , or $18^{\circ} \mathrm{C}$ in a greenhouse.

\begin{tabular}{|c|c|c|c|c|c|c|}
\hline \multicolumn{4}{|c|}{ Storage treatment } & \multirow[b]{2}{*}{ Marketability (\%) } & \multirow[b]{2}{*}{ Time to flower (d) } & \multirow[b]{2}{*}{ Stems (no./bulb) } \\
\hline Temp $\left({ }^{\circ} \mathbf{C}\right)^{\mathrm{z}}$ & Removed & Duration (d) & Environment $^{\mathrm{y}}$ & & & \\
\hline \multirow[t]{4}{*}{2} & Yes & 96 & Cooler & $100 a^{x}$ & $199 \mathrm{abcd}$ & $0.2 \mathrm{f}$ \\
\hline & & 54 & & $100 \mathrm{a}$ & $212 \mathrm{a}$ & $0.4 \mathrm{def}$ \\
\hline & & 47 & & $100 \mathrm{a}$ & $207 \mathrm{ab}$ & $0.8 \mathrm{bc}$ \\
\hline & No & & Greenhouse & $100 \mathrm{a}$ & $211 \mathrm{a}$ & $0.9 \mathrm{~b}$ \\
\hline \multirow[t]{5}{*}{10} & Yes & 96 & Cooler & $75 \mathrm{a}$ & $202 \mathrm{abc}$ & 0.4 def \\
\hline & & 80 & & $67 \mathrm{a}$ & 190 bcde & $0.3 \mathrm{ef}$ \\
\hline & & 54 & & $100 \mathrm{a}$ & $205 \mathrm{abc}$ & $0.3 \mathrm{ef}$ \\
\hline & & 47 & & $100 \mathrm{a}$ & $207 \mathrm{ab}$ & $0.3 \mathrm{ef}$ \\
\hline & No & & Greenhouse & - & - & - \\
\hline \multirow{5}{*}{18} & & 54 & & $0 \mathrm{~b}$ & $171 \mathrm{e}$ & $0.1 \mathrm{f}$ \\
\hline & & 47 & & $100 \mathrm{a}$ & $186 \mathrm{cde}$ & $0.3 \mathrm{ef}$ \\
\hline & No & & Greenhouse & - & - & - \\
\hline & & & Cooler & $100 \mathrm{a}$ & $182 \mathrm{de}$ & $0.4 \mathrm{def}$ \\
\hline & & & Outside & $75 \mathrm{a}$ & $204 \mathrm{abc}$ & $0.7 \mathrm{bcd}$ \\
\hline Significance $^{w}$ & & & & $<0.001$ & 0.001 & $<0.001$ \\
\hline
\end{tabular}

are hardy to Zone 8 (Bryan and Griffiths, 1995); however, these hybrids have been shown to be hardy in Raleigh, NC (Zone 7b). Studies at Cornell University have shown other pineapple lily hybrids to be hardy in Zone 5 in unheated high tunnels or mulched (W.B. Miller, personal communication). Our emergence data suggests that it may be cumulative because for some cultivar bulbs stored for longer periods at warmer temperatures had similar emergence heights to bulbs stored for shorter periods at colder temperatures. Our flowering data has similar trends; for example, 'Cream' pineapple lily stored outside $\left(5{ }^{\circ} \mathrm{C}\right)$ for $47 \mathrm{~d}$ and stored in the cooler $\left(13{ }^{\circ} \mathrm{C}\right)$ for $96 \mathrm{~d}$ flowered at the same time. 'Lavender' pineapple lily may require more chilling hours than the other cultivars according to its change in stem marketability. As the production temperature decreased, the number of marketable stems increased to $100 \%$ regardless of storage treatment. This may be due to the $2{ }^{\circ} \mathrm{C}$ house staying colder longer, allowing it to fulfill its chilling requirement better than in warmer houses. This cold requirement does not appear to be obligatory since the treatments that were not cooled (stored in a greenhouse) still flowered with marketable stems.

The combination of being removed from the substrate, stored for long lengths of time and then grown in high temperatures may not have allowed for sufficient root formation and could account for the lack of flowering in the two treatments stored for 96 or $80 \mathrm{~d}$ in the cooler removed from the substrate and grown at $18{ }^{\circ} \mathrm{C}$. Amaryllis (Hippeastrum) will not flower if the bulbs were harvested when physiologically immature, not stored long enough, improperly stored after harvest, or have a poor root system (De Hertogh, 1996). Lee and Roh (2001) found that high greenhouse forcing temperatures during the summer accelerates flowering, resulting in short plants, and increased number of abnormal flowers in oriental hybrid lilies
'Acapulco' and 'Simplon' after frozen storage.

\section{Conclusion}

Successful production of pineapple lily can be achieved in different production scenarios. Even with the changes in stem length and caliper from the different production environments, planting densities, and production year, the stems were still of marketable quality that would be suitable for cut flowers. Knowing the effects these factors can have on stem quality is important for growers so they can anticipate changes in their product. Pineapple lily is well suited for field or greenhouse production and may also be appropriate for unheated high tunnels. It may be grown for one season in crates in greenhouses or potentially outside or as a perennial in the field in suitable climates. If grown for multiple seasons, a low planting density should be used to allow for subsequent years growth of bulblets. If grown for just one season, a high planting density 
has no adverse effects. It would be best for growers to leave bulbs in substrate from season to season and cold store for at least $47 \mathrm{~d}$ or dry store in a greenhouse until ready to force. To hasten flowering, warmer forcing temperatures are ideal. Pineapple lily offers growers versatility in production environment and planting density to suit individual needs and still produce marketable stems.

\section{Literature cited}

Bryan, J. and M. Griffiths. 1995. Manual of bulbs. Timber Press, Portland, OR.

Carlson, A.S. and J.M. Dole. 2014. Postharvest handling recommendations for cut pineapple lily. HortTechnology 24:731-735

De Hertogh, A.M. 1996. Holland bulb forcer's guide. 5th ed. Alkemade Printing, Lisse, The Netherlands.

De Hertogh, A. and M. Le Nard. 1993. The physiology of flower bulbs. Elsevier, Amsterdam, The Netherlands.
De Hertogh, A., A.N. Roberts, N.W. Stuart, R.W. Langhans, R.G. Linderman, R.H. Lawson, H.F. Wilkins, and D.C. Kiplinger. 1971. A guide to terminology for the Easter lily (Lilium longiflorum Thunb.). HortScience 6:121-123.

de Vroomen, C.O.N. 1974. Economic evaluation of differences in planting densities. Acta Hort. 47:399-406.

Dole, J.M. and H.F. Wilkins. 2005. Floriculture: Principles and species. 2nd ed. Prentice Hall, Upper Saddle River, NJ.

Halevy, A.H. 1990. Recent advances in control of flowering and growth habit of geophytes. Acta Hort. 266:35-42.

Hartsema, A.M. 1961. Influence of temperatures on flower formation and flowering of bulbous and tuberous plants. Encycl. Plant Physiol. 16:123-161.

Lee, J.S. and M.S. Roh. 2001. Influence of frozen storage duration and forcing temperature on flowering of oriental hybrid lilies. HortScience 36:1053-1056.

Luria, G., D. Weiss, O. Ziv, and A. Borochov. 2005. Effect of planting depth and density, leaf removal, cytokinin and gibberellic acid treatments on flowering and rhizome production in Zantedeschia aethiopica. Acta Hort. 673:725-730.

Ortiz, M.A., K. Hyrczyk, and R.G. Lopez. 2012. Comparison of high tunnel and field production of specialty cut flowers in the Midwest. HortScience 47:12651269.

Rees, A.R. 1974. Spacing experiments on bulbs: Principles and practice. Acta Hort. 47:391-396.

Roh, M.S. and D. Hong. 2007. Inflorescence development and flowering of Ornithogalum thyrsoides hybrid as affected by temperature manipulation during bulb storage. Sci. Hort. 112:60-69.

Roh, M.S., A.K. Lee, and J.K. Suh. 2007. Induction of bulb maturity of Ornithogalum thyrsoides. Sci. Hort. 114:138-141.

Roh, S.M. and H.F. Wilkins. 1978. The effects of bulb vernalization and shoot photoperiod treatments on growth and flowering of Lilium longiflorum Thunb. cv. Nellie White. J. Amer. Soc. Hort. Sci. 102:229-235.

Wien, H.C. 2009. Floral crop production in high tunnels. HortTechnology 19:56-60. 